\title{
Rethinking the Origins of Civic Culture and Why it Matters for the Study of the Arab World (The Government and Opposition/Leonard Schapiro Lecture 2018)
}

\author{
Carrie Rosefsky Wickham* \\ Carrie Rosefsky Wickham, Emory University, Atlanta, Georgia, USA \\ ${ }^{*}$ Corresponding author. Email: cwickha@emory.edu
}

(Received 15 October 2018; revised 28 January 2019; accepted 11 February 2019; first published online 2 April 2019)

\begin{abstract}
The protests of the Arab Spring sparked hope for a democratic breakthrough in a region long known for its durable systems of authoritarian rule, but optimism soon turned to disappointment. This article argues that the main problem with the post-Arab Spring narrative of failure and regression is that it equates democratization with regime change and places too great a causal burden on protests as the route to its achievement. It proposes that democratization can be understood as a multivalent process encompassing changes occurring at different registers, spurred by different causal mechanisms, and according to different time lines, rather than as a fixed package of changes that proceed in unilinear fashion from different variants of authoritarianism towards a common democratic finish line. Thinking about democratization differently alerts us to vectors of change we might otherwise fail to notice and enables us to move beyond the over-generalizations and over-simplifications that arise when we focus solely on (changes in) macro structures and relations of power.
\end{abstract}

Keywords: Arab Spring; Arab Winter; modernization theory; authoritarianism; democratization; Arab world; regime change; Islamic humanism; prefigurative politics; the art of presence

The protests of the Arab Spring, unfolding in real time, seemed poised to effect a sudden break from the region's long history of authoritarian rule (Bellin 2004). One need only recall the image of strangers embracing in Tahrir Square on 11 February 2011, the night Egyptian President Hosni Mubarak stepped down, to appreciate the euphoria demonstrators felt as they witnessed what they thought was the crumbling of the old order and imagined the bright future looming just over the horizon. Western leaders got caught up in the excitement as well. As US President Obama confidently declared a few months later: 'Across the region, those rights

This article is based on the Government and Opposition/Leonard Schapiro Lecture, but was substantially expanded and revised following the lecture's presentation in March 2018.

(c) The Author 2019. Published by Government and Opposition Limited and Cambridge University Press. 
that we take for granted are being claimed with joy by those who are prying loose the grip of an iron fist' (Washington Post 2011).

Such optimism soon yielded to bitter disappointment. Not only was the democratic dividend of the Arab Spring far more modest than expected, but even worse, the forces of change it unleashed have generated added misery in the form of resurgent authoritarianism, state breakdown, civil war and religious extremism. As neatly expressed in the reigning trope $d u$ jour, the Arab Spring has morphed into an Arab Winter (Elshinnawi 2016).

In retrospect, it is clear that the protests of the Arab Spring generated outsized hopes they could not fulfil. Massive displays of 'people power' can destabilize and even topple entrenched authoritarian regimes, but they cannot generate democracy on their own. Why the protests of the Arab Spring failed to instigate a successful democratic transition in any Arab state but Tunisia merits careful examination, and in recent years a number of excellent scholarly books and articles have come out which analyse the post-Spring trajectories of Arab states in wider theoretical, comparative and historical perspective. ${ }^{1}$ At the broadest level, the disappointments of the post-Spring era underscore the fact that there is no magic wand that can make long-standing patterns of economic under-development, political repression, corruption and social polarization disappear overnight. Overcoming such legacies is apt to be a difficult and protracted process, requiring a sustained mobilization of political will, organization and resources. Even in Tunisia, the lone 'success story' of the Arab Spring, such institutional legacies are still in play, adding to the burdens of elected officials at a critical early phase of the country's experiment in self-rule.

That significant obstacles to the democratic reform of Arab states and societies persist and are likely to endure for a long time to come brooks no dispute. Nor is there any denying the stultifying effects of the post-Spring 'authoritarian turn', in which unelected officials in many Arab states have deployed a mix of carrots and sticks - or resorted to outright repression - to secure their grip on power in the face of growing popular unrest. Yet the image of the region as nothing but an unbroken landscape of limitation and constraint risks flattening out and homogenizing a more complex and differentiated reality.

The problem with the post-Arab Spring narrative of failure and regression is that it equates democratization with regime change, and places too great a causal burden on mass protests as the route to its achievement. To many observers, the 'modest harvest' of the Arab Spring indicates that democratization in the region has stalled. If we are talking about democratization in the usual sense - i.e. equating it with change in macro-level structures and relations of power - this depiction rings true. But 'democratization' also lends itself to a more holistic conceptualization. Let me suggest here that it can be understood as a complex, multivalent process encompassing different strands of change, spurred by different causal mechanisms, occurring in different domains and proceeding according to different time lines. What we see depends on where we look, and thinking about democratization differently alerts us to vectors of change we might otherwise fail to notice. Extending our gaze beyond the domain of formal politics does not necessarily or automatically yield a rosier picture of a particular society's democratic prospects. But it does enable us to move beyond the over-generalizations and over-simplifications that 
arise when we define those prospects solely in terms of its aggregate structures and relations of power.

\section{Extending the study of democratization beyond regime change}

Much of the political science literature on democratization focuses on the dynamics of regime change, that is, on transitions from political systems which concentrate power in the hands of unelected rulers to those in which the highest positions of executive and legislative authority are filled through free and fair elections and citizens are granted a broad range of civil and political rights, typically enumerated in a written constitution. ${ }^{2}$ Supplementing the scholarly analysis of 'democratic transitions' is a companion literature on 'democratic consolidation': on whether, when and how democratic norms and practices become institutionalized after power has been formally transferred to elected public officials. Studies of 'democratic consolidation' hence extend their purview beyond the occurrence of democratic regime change as a discrete event to investigate the scope and limits of subsequent institutional reforms, such as efforts to subject the military and police to effective civilian oversight, build an independent judiciary and strengthen the rule of law. While studies of democratic transition seek to explain how institutions of democratic governance come into being, studies of democratic consolidation seek to identify the causal pathways and conditions which impact their quality and effectiveness.

Yet as vital as establishing the political institutions of self-rule may be, democratization in its fullest sense exceeds it. This is because the ability of individuals to exercise the rights guaranteed to them by law requires the active complicity of their fellow citizens, a point stressed by Amartya Sen in his seminal work, Development as Freedom (1999: 282-298). This is particularly true if we conceive of 'democracy', or 'rule by the people', not just as embodying the collective authority of citizens to select their leaders but also, and equally fundamentally, their rights and capabilities as individuals to lead lives of their own choosing - that is, to rule themselves. Sen's key insight is that rights guaranteed by law cannot be realized in practice without some degree of citizen buy-in, since most social interactions take place outside the reach of direct state control. If it is social norms, as much as laws, which endow citizens with meaningful agency and enable them to live peaceably with each other, then it behooves us to investigate how authoritarian legacies are overcome, not just at the level of formal institutions but also in the domain of social relations and the interior of the human psyche.

Seen from this vantage point, democratization encompasses a range of ideational, cultural, psychological, emotional and affective dimensions that remain under-theorized and empirically under-explored. As a heuristic tool (and an exercise in creative concept-stretching), I propose the term 'deep democratization' to refer to the formation of social norms and institutions which enable individuals to see themselves, and each other, as possessing equal intrinsic worth and dignity as fellow human beings. 'Deep democratization' is thus an analytic shorthand for the development of a robust humanistic culture.

Since the term 'humanism' lends itself to different interpretations, let me clarify how I define it. A humanist world-view is one that imagines every person to be equal in their intrinsic worth, while simultaneously acknowledging each person's 
radical uniqueness as the bearer of an independent 'self'. Such a world-view need not conflict with the assignment of identities to oneself or others based on gender, kinship, ethnicity, religious sect or ideology. It is, however, very different from one which posits such identities as trumping the salience of our common humanity and the radical uniqueness of each person's inner self. ${ }^{3}$

According to this definition, one need not be secular, modern or Western to be a humanist. A rich vein of humanist thought can be found in the discursive traditions of many world civilizations, bound up in spiritual, philosophical and religious contemplation of the meaning of human existence and its place in the order of the cosmos. Further, even in societies where religious beliefs, social customs and/ or systems of law work to privilege some individuals and groups over others, one can find instances in which people choose to treat those assigned lesser status with empathy and respect. For example, humanist ideas and practices can be realized in the micro-dynamics of love relationships, family life and communal bonds, in ways that quietly but powerfully challenge reigning systems of social hierarchy, discipline and control.

If the values and practices of Arab-Islamic societies are more complex and internally differentiated than is often acknowledged, the same is true of cultural patterns in the West. Characterizing Western democracies as humanistic is overly self-congratulatory. For there too, humanist ways of relating to oneself and others continue to come up against rival ideologies of extremism and intolerance, whether in the form of racism, male chauvinism, homophobia, ultra-nationalism or religious fundamentalism. Second, persistent acute inequalities of income, knowledge and social capital in even the richest and freest societies limit the capacity of many people to exercise meaningful agency in their daily lives. For those at the bottom of the social ladder, the human liberation promised by democracy and economic development has yet to arrive. In sum, modern complex societies vary in the extent to which they privilege humanist ideals, but none can be said to have established social arrangements in which they have been fully realized in practice.

\section{Conceptualizing 'civic culture'}

In the discipline of political science, scholars have identified a particular matrix of values as uniquely supportive of the effective functioning of democracy, which they refer to as a 'civic culture'. Sidney Verba and Gabriel Almond introduced the concept in their landmark study, Civic Culture: Political Attitudes and Democracy in Five Nations (1963), which investigated whether or not (and to what extent, and in what ways) the value orientations of ordinary citizens facilitate the installation of democratic systems of governance and enable them to thrive. Verba and Almond described a robust 'civic culture' as encompassing an optimal mix of parochial, subject and participant values. In particular, citizens combine: (1) a basic trust in government officials typical of 'subject' cultures with (2) the feelings of efficacy and competence associated with 'participatory' cultures. As aptly summarized by Tomasso Pavone (2014), it is the mixed quality of 'civic culture' that mediates the contradictions inherent in democratic systems, namely, the tension between government effectiveness and government accountability. 
Both the longevity of the concept of 'civic culture' and the lively intellectual debate it has inspired about the connections between citizens' values and macro institutions of power speak to the importance of Verba and Almond's contribution. ${ }^{4}$ At the same time, it has come under critique from a variety of standpoints (see, for example, Laitin 1995; Lichterman 2012; for Almond and Verba's response to some of the critiques, see Almond and Verba 1980; Verba 2015). As I see it, the most vexing problem is that the effects of 'trust' and 'competency' are contingent upon the higher-order values that inform them. The consequences of 'trust' depend on the values which inform the behaviour of public officials; likewise, the consequences of 'efficacy' and 'competency' depend on how citizens view themselves and each other. When humanist values are weak, high levels of participation can end up undermining tolerance and inclusivity, as demonstrated by numerous instances of fascist, communist, ultranationalist and 'fundamentalist' religious mobilization across time and place.

Further, the literature on 'civic culture' focuses on citizens' behaviour in the public sphere - i.e. as voters, members of political parties and participants in civic associations - while giving short shrift to social interactions in such ostensibly 'non-political' settings as the school, the workplace and the home. Yet asymmetries of power exist and are susceptible to abuse in these domains as well. Not only are government officials invested with power, but so too are teachers, parents, spouses, bosses and religious authorities. ${ }^{5}$ Hence, an investigation of the relationship between popular habits of mind and behaviour and the structure and operation of power in a given society must extend beyond a focus on citizens' interactions in the public domain to encompass how citizens relate to each other in communal and private settings as well.

If 'civic culture' is best conceptualized as the larger matrix of norms and values that inform human interactions in all spheres of public and private life, what is it that distinguishes 'civic' norms and values from their alternatives? From a liberal standpoint, the most important of all civic values is the individual's right to selfexpression and the tolerance of difference that this implies. As Ronald Inglelhart and Christian Welzel argue:

The core of the human development sequence is the expansion of human choice and autonomy ... Cultural emphasis shifts from collective discipline to individual liberty, from group conformity to human diversity, and from state authority to individual autonomy, giving rise to a syndrome that we call self-expression values ... Rising self-expression values transform modernization into a process of human development, generating a society that is increasingly people-centered. This reflects a humanistic transformation of modernity. (Inglehart and Welzel 2005: 2-3)

I agree that a commitment to individual autonomy and choice lies at the heart of a humanist culture. Nevertheless, this definition strikes me as incomplete for two reasons. First, a humanist culture is arguably not just one which allows individuals to 'be themselves', but also one which enables individuals to cultivate a deeper and richer sense of Self than one oriented towards the gratification of immediate impulses and desires. In the West, one of the primary routes towards this kind 
of self-development, dating back in some form to Ancient Greece, was the training of citizens in the 'liberal arts', literally, the ways of thinking and living worthy of a free person. One can find a similar emphasis on self-cultivation in the ethical teachings of other civilizations as well. For example, in the Muslim world, it gained expression in the Sufi idea of 'tazkiyat an-nafs', or 'refinement of the soul', through which people seek to free themselves of the tyranny of their own egos and actuate the divine spark within. ${ }^{6}$ A central insight of such traditions is that some of the greatest constraints to individual freedom lie within the interior of the human psyche, including the base impulses of greed, domination and aggression, as well as addictions to food, sex, drugs, gambling and/or mind-numbing entertainment. Indeed, one might go so far as to claim that individual 'freedom' in the fullest sense is not possible without some prior investment in the cultivation of the Self through intensive learning and self-discipline, for it is through this process that the individual's horizon of choice widens to encompass sources of meaning and purpose that are inaccessible without it.

A second argument in favour of a more expansive concept of humanist culture has been articulated by communitarian and 'constructivist' postmodernist theorists who advocate an ethic, or guide to living, which balances respect for individual rights with concern for the public good. At the core of this outlook is an emphasis on the vulnerability and interdependence of all living (and non-living) things, and hence of the moral imperative for human beings to assume stewardship for the well-being of the community, the nation, the world and all of Creation. ${ }^{7}$

Human freedom and fellowship can be thought of as 'social imaginaries', not in the sense that they are fictions, but rather in that they are products of the human imagination that can only be actuated or literally 'brought to life' through changes in social norms and institutions, not just in the public sphere but in the most intimate domains of private life as well. What distinguishes a 'humanist culture' is not the complete realization of such imaginaries (this sets the bar too high), but their wider resonance as ideals worth aspiring to.

How, when and why do humanist culture shifts occur? Let us review what the political science literature has to say on this matter.

\section{Rethinking the origins of civic culture}

In the post-World War II era, scholars in the emerging field of behavioural social science sought analytic leverage on the question of how democracies emerge and manage to survive internal and external challenges. In the 1950s and 1960s, such research coalesced in a new school of thought known as 'modernization' theory. Modernization scholars proposed that all societies proceed along a single linear path of human development. The transition to modernity entailed industrialization, urbanization and the spread of literacy, education and mass communications, with predictable results. In particular, such broad structural changes led to the empowerment of the people and their embrace of secular democratic values, and, in so doing, set the stage for democracy to emerge and thrive (see, for example, Deutsch 1961; Lerner 1958; Lipset 1959).

Classic 'modernization' theory later came under attack by scholars who claimed that its proposed sequence of human development was too linear and deterministic. 
As many observed, there is no 'iron law' of history that culminates in democracy because the cultural and political effects of industrialization are context-dependent. Moreover, many countries have undergone political transitions to democracy when the economic and cultural conditions deemed important by modernization theorists were absent. Taking this line of critique even further, scholars associated with the emerging field of 'rational choice' argued that the logic of democratic transitions has little to do with culture at all. Building on the work of Dankwart Rustow (1970), they argued that transitions to democracy are the result of bargains among rival elites who are relatively equal in power. When no one group is in a position to achieve dominion over its competitors, elites support democracy as the 'next best option'. Hence it is the self-interested behaviour of elites, not culture change, which drives the transition process. ${ }^{8}$

To the extent that rational choice scholars were interested in the formation of a 'democratic' or 'civic' culture, they viewed it as a product of regime change. That is, once the political institutions of democracy were in place, citizens acquire democratic values through their iterative participation in the democratic process what scholars following Rustow (1970) have referred to as 'democratic habituation'. While early modernization theorists viewed the rise of a civic culture as an essential precursor to the rise of democratic systems of governance, rational choice institutionalists reversed the causal arrows: democratic regime change comes first, followed by the rise of a democratic culture.

In recent years, scholars advocating an updated version of 'modernization' theory have articulated a powerful challenge to the rational choice institutionalist model. Nowhere is this challenge more powerfully articulated or better empirically supported than in Ronald Inglehart and Christian Welzel's Modernization, Culture Change and Democracy: The Human Development Sequence (2005). Hailed as a tour de force, Inglehart and Welzel's book draws on three decades of cross-national public opinion survey data to rescue culture from its critics (Inglehart and Welzel 2005: 157-160). In particular, they argue that it is more plausible that 'the dominant causal direction in the relation between human values and democratic institutions runs from values to institutions rather than the reverse', a claim they support through a deft combination of substantive argumentation and rigorous empirical analysis (Inglehart and Welzel 2005: 159).

Inglehart and Welzel admit that the linear development model proposed by earlier modernization theorists was too simplistic, and yet, they argue, its underlying logic is sound. They refine the classic model in two ways. First, they argue that modernization entails two distinct phases, industrialization and postindustrialization, and it is the latter which occasions the spread of the 'postmaterialist' values that are so crucial to the effective functioning of democracy. In rich post-industrial societies, the survival needs of ordinary citizens have been met, freeing them to prioritize individual self-expression and to concede the same autonomy to others. And yet, Inglehart and Welzel note, to a greater degree than early modernization theorists anticipated, culture is 'sticky': that is, longstanding cultural traditions affect the pace at which 'post-materialist' values are absorbed. Nevertheless, once the existential needs of citizens are met, all societies, no matter what their starting points, are bound to shift in a humanistic direction (Inglehart and Welzel 2005: 45-47, 48-76). 
In sum, Inglehart and Welzel propose a uniform sequence of human development which, in its later stages, becomes an emancipatory process that enlarges the scope for human agency. ${ }^{10}$ Over the long term, this view of development is profoundly optimistic, as all human societies will eventually become freer, more tolerant and more inclusive. Yet in the shorter term, the prospects for the emergence of a robust humanistic culture in the Middle East and North Africa are bleak, given that the survival needs of much of the population have not been met. If structural change is the motor of emancipation, the values of human freedom and fellowship cannot take hold unless and until structural conditions are right. Indeed, high rates of poverty and joblessness in many Arab states, as well as the continuing brakes on economic development posed by state breakdown and civil war in some places, and resurgent authoritarianism in others, place the kind of system-wide emancipation envisioned by Inglehart and Welzel out of reach for the foreseeable future.

Classic modernization theory, rational choice institutionalism and revised modernization theory explain the rise of 'civic culture' in different ways, but they share some common limitations. In my critique, I will focus on proponents of the latter two models, namely, the 'institutionalists' on the one hand, and the 'revised modernization' or self-defined 'culturalist' scholars like Inglehart and Welzel, on the other.

'Institutionalists' and 'culturalists' diverge on the question of which comes first, the emergence of a civic culture or the installation of a democratic system of governance. ${ }^{11}$ Yet the logic of their causal models is remarkably similar, as both frame the rise of a civic culture as a product of broad structural changes beyond the scope of conscious human control. For the 'institutionalists', the springboard for culture change is the rise of formal democratic institutions; for the 'culturalists', it's the shift from industrialist to post-industrialist societies. What is noteworthy is that in both models, culture change is epiphenomenal; that is, the result of something else.

For students of the Arab world, this begs the question of whether humanist culture change must await the onset of broader processes of political liberalization and/ or economic development that are likely to unfold over a long time horizon, if they occur at all.

Do political and economic conditions in the region in the wake of the Arab Spring negate all possibilities for humanist culture in the meantime? My answer is no. Asymmetries of power in the region, and the complex web of institutions and ideas deployed by stakeholders to justify and preserve them, pose significant constraints on the occurrence of humanist culture change but do not obviate it altogether. To suggest otherwise smacks of a structural determinism that falsely associates unpropitious political and economic conditions with system-wide stasis. In particular, prevailing models obscure two alternative causal pathways to humanist culture change which are of direct relevance for the study of the Arab world.

\section{Rethinking the structural drivers of culture change}

To begin, let's accept the premise that humanist culture change is a product of broad, impersonal structural forces beyond the reach of direct human control. 
Even if this is true, prevailing models err in assuming that the structural drivers of humanist culture change are uniform across cases. In particular, by framing such change as a by-product of freedom and prosperity, they fail to acknowledge that conditions of adversity can in some instances generate humanist culture change as well.

A new report on gender attitudes in the Arab world by Promundo (El Feki et al. 2017), a global non-governmental organization, based on field research in Egypt, Morocco, Lebanon and the Palestinian Authority, highlights this trend. In particular, it revealed that women's assumption of greater responsibilities for their families when their husbands were imprisoned or forced by circumstance to work away from home for sustained periods of time prompted some of the men included in the survey to develop greater respect for their wives and start relating to them more as equal partners. In sum, conditions of repression and economic privation worked to unsettle the authority of the male head of household and, in so doing, prompted the formation of relationships between men and their wives and adult children marked by higher levels of mutual interdependence, cooperation and trust (El Feki et al. 2017: 19, 228, 242, 252).

To avoid misunderstanding, let me emphasize that the cultural effects of adversity are context-dependent. I am not suggesting that adversity is always or necessarily a harbinger of humanist culture change. Neither am I making any broader claims about the magnitude of the trend described above (i.e. how many people it applies to), nor denying that patriarchal attitudes and practices remain deeply entrenched in Arab societies. Nevertheless, the Promundo study demonstrates that humanist culture change is possible under conditions that are not just different from, but the inverse of, those deemed salient in Inglehart and Welzel's model.

Other trends captured by the Promundo report are relevant as well. While indicating that a majority of men and women endorsed the right of male heads of household to regulate and control the behaviour of their female relatives in various ways, it also demonstrated that Arab public opinion on gender issues is far from monolithic. Indeed, a quarter to a third of the Arab men included in the survey expressed support for advances in women's rights at home, in the workplace and in the domain of politics, with higher levels of support for gender equality observed among men with higher levels of education and with fathers who had participated in child-rearing and household chores during the formative years of their childhood (for a discussion of general trends, see El Feki et al. 2017: 14-20, 256-264). In sum, the study reveals the salience of social changes independent of, or at least nonreducible to, increases in political freedom and/or economic wealth and resources as structural drivers of progressive attitude-change on gender relations in the Arab world.

Moreover, conditions of repression and adversity can spur the formation of a 'resistance subculture' in which the normal rules that regulate social life are suspended and new forms of social solidarity are created. We see this occurring within the context of national liberation movements, both within the Middle East and outside it (on Middle East cases, see, for example, Badran 1998; Deeb 2006; Moghadam 1994). And we see a similar process at work during the Arab Spring protests. For example, in Why Occupy a Square? People, Protests and Movements in the Egyptian Revolution, Jeroen Gunning and Ilan Zvi Baron chart the formation 
of the 'Republic of Tahrir' during the 25 January uprising, a space in which men and women, Muslims and Christians, and citizens from disparate walks of life created a new model of self-governance based on relations of mutual fellowship and respect (Gunning and Baron 2014: 241-274). Resistance subcultures can develop on a smaller scale as well, with similar effects. The important point is that in all of these cases, conditions of repression and adversity not only did not prevent the occurrence of humanist culture change but actually helped to set it in motion.

\section{The art of presence: human initiative, social networks and culture change}

As demonstrated above, the structural drivers of humanist culture change are more varied and diverse than prevailing models allow. At the same time, such models fail to consider instances of culture change which are not a product of broad structural forces, but rather an outcome of purposive human endeavour - that is, of creative social experimentation under existing institutional constraints.

Let me begin by acceding some ground to the sceptics. There is no denying that some environments are more conducive to social innovation than others. Authoritarian restrictions on freedom of assembly and expression, resource scarcity, bureaucratic inertia and widespread corruption can all be said to limit the space for human initiative and diminish its potential impact, regardless of the purposes to which it is directed. And yet, it is only in extreme cases, such as under conditions of absolute poverty, totalitarian rule and/or state breakdown and civil war, that the prospects for social experimentation become so constrained as to nearly vanish altogether.

The implications of this point for Arab societies in the post-Spring era are discussed by Asef Bayat (2015) in his seminal essay, 'Revolution and Despair', published on the independent Egyptian website Mada Masr. Drawing on the work of Antonio Gramsci, Bayat argues that even under the shadow of authoritarian states and neoliberal economies, citizens can work to 'foster and facilitate creating a novel, inclusive and egalitarian social order' by engaging in the 'art of presence', that is, by mobilizing 'the courage and creativity to assert [their] collective will in spite of all odds by circumventing constraints, utilizing what is possible, and discovering new spaces within which to make themselves heard, seen, felt, and realized' (Bayat 2015). Through social experimentation at the micro level - i.e. within particular communities, institutional settings and/or areas of endeavour - citizens can work to enact the kinds of changes they would like to see in society at large. Scholars of social movements and contentious politics have developed the concept of 'prefigurative politics' to capture the efforts of groups and movements to embody 'those forms of social relations, decision-making, culture, and human experience that are [their] ultimate goal' (Carl Boggs, quoted in Raekstad 2018: 362). ${ }^{12}$ This concept has been applied to the study of religious movements, revolutionary socialist movements, the Indian national independence movement and the American civil rights movement. Without too much concept-stretching, it can arguably be extended to an even broader range of cultural initiatives, including smaller-scale efforts which do not rise to the level of a 'movement' per se. Community activists, educators, professionals, religious authorities and public officials, as well as writers, 
filmmakers, artists and musicians, can give expression to humanist ideas and practices and, through various forms of outreach, introduce them to members of the wider public. Initially the circle within which such new ideas gain traction may be small, but they can eventually spread upwards and outwards through networked relationships, and/or by gaining the support of trend-setters in the government, the media, the religious establishment, the education system or the domain of 'civil society'. Such new ideas may attract a growing number of followers, and/or generate resistance. But regardless of their fate, the broader point still holds: namely, that social networks constitute an autonomous zone of purposive human endeavour. How such networks form, who participates in them, and whether or not they are able to circulate new models of thinking and acting among wider sectors of the mass public is, of course, shaped by the political and economic environment within which they are embedded. And yet, what goes on within them is not reducible to, or functionally derivative of, the nature of a country's political institutions or level of economic development.

In order to investigate the possibilities for humanist initiatives under conditions of authoritarian constraint, we must turn our attention away from aggregate trends towards manifestations of social variation, nuance and complexity. To begin with, we must discard the assumption that democratic regimes correspond with egalitarian and pluralist societies, while authoritarian regimes lock in authoritarian values and social structures all the way down. The Arab Human Development Report of 2004 (UNDP 2005) observed that the authoritarian practices of Arab ruling elites correspond with authoritarian practices at the level of the family, the schools, the religious establishment and other social institutions. As the report so eloquently puts it: 'The crisis in political structures is reflected in Arab societal structures that consist of embedded links in an interconnected chain constricting freedom' (UNDP 2005: 17). The connections between authoritarian political and social structures are real and of great importance. At the same time, we should approach systems of authoritarian rule with an eye for tensions, disjunctures, gaps and discontinuities, the places where experimentation is possible and dominant beliefs and practices can be challenged or overturned. Indeed, every link in the chain identified by the authors of the Arab Human Development Report represents a potential site of contestation. Moreover, not all links are the same: some of them are tighter and others looser, i.e. less or more susceptible to transformation, depending on the particular configuration of power and interests surrounding it.

Two key points are worth emphasizing here. First, authoritarian rulers may seek, above all, to maintain their grip on power. Yet even if they prioritize their own narrow interests first and foremost, it is not at all obvious what course of action they should pursue, because the conditions favouring regime survival are difficult to unravel. Second, the agendas of authoritarian rulers are rarely one-note in character. On the contrary, they typically include a wide range of second-order goals, such as meeting public demands for services, boosting economic growth or enhancing the regime's public image abroad. In sum, at a more granular level, the agendas of such rulers encompass multiple and conflicting objectives which differ across cases, as do the institutional capabilities, resources and strategies available to pursue them. While some authoritarian rulers seek to preserve power through high levels of system-wide coercion, others deploy coercion more selectively and seek out 
opportunities for constructive engagement with non-state actors when their goals align.

Added to this is the fact that authoritarian regimes are not monolithic. Rather, they are large and complex institutions encompassing officials with diverse interests and orientations who do not always or necessarily march in lockstep to the beat of the same drum. In many cases, certain officials positioned within certain state institutions possess some measure of autonomy to pursue agendas of their own making, in line with how they understand their own interests and/or those of society at large. Hence we must guard against exaggerating authoritarian regimes' internal discipline and coherence, and avoid the a priori assumption that state officials and civil society activists in authoritarian settings always and necessarily relate to each other as adversaries. Even when the power balance between them is highly asymmetrical and their interests and objectives differ, state and non-state actors may discern mutual benefit in working together.

Of course, the fact that opportunities for social experimentation may exist under conditions of authoritarian constraint does not necessarily bode well for democratization, as not all self-generating cultural initiatives are humanist in orientation. On the contrary, communist, fascist, ultra-nationalist and religious fundamentalist groups and movements also engage in meaning-making through social networks. Such efforts can generate ideas and institutions that legitimate and sustain new patterns of dominion and control, diminishing the scope for human agency rather than enlarging it. For this reason, the rise of strong 'civil society' organizations independent of the state does not in and of itself support the development of a robust 'civic culture' (see Cavatorta 2015 and also Berman 1997).

In my book, Mobilizing Islam: Religion, Activism and Political Change in Egypt (Wickham 2002), I showed how ideological outreach and institution-building by Islamist groups gave rise to new forms of social organization at the grassroots level, laying the foundations of a 'parallel society'. Indeed, one of the primary achievements of the Islamist movement was the formation of a distinctive subculture marked by new forms of social solidarity as well as new forms of social control. The richness and complexity of this new Islamist subculture make it difficult to pigeon-hole as 'liberal' or 'illiberal'; Islamist meaning-making through social networks helped expand individual agency in some ways while diminishing it in others. The point I wish to make here is that the same type of network analysis that I applied to the study of Islamist mobilization can be utilized to investigate instances of 'pre-figurative politics' informed by humanist values and sensibilities as well.

\section{Humanist initiatives in the Arab world: a brief overview}

There is no denying that the post-Spring 'authoritarian turn' and the persistence of ongoing problems of economic stagnation, corruption, sectarian violence and religious extremism constitute formidable obstacles to the democratic reform of Arab states and societies. Yet obstacles to change at the aggregate level do not necessarily preclude change at the micro level. In particular, creative social experimentation in localized arenas can set new trajectories of change in motion, even when pathways to regime change are blocked. 
Within the Arab world, we find multiple initiatives in the fields of education, religion and public culture occurring now, in real time, within different institutional settings, involving different configurations of state and non-state actors, and oriented towards different immediate objectives which, despite their diversity, can be seen as facets of a wider humanist project. This is because, in different ways, all of them seek to enlarge the scope for human freedom, creativity, critical inquiry and social solidarity within an Arab-Islamic context. Such a framing serves to destabilize conventional distinctions between 'state' and 'society', 'Islamists' and 'secularists', and 'elite' and 'popular' culture, and, in so doing, enables us to explore actual and potential vectors of change which transcend these divides.

Humanist initiatives underway in the region are too many to enumerate, so let me offer just a few examples. In the Palestinian Authority, Kuwait, Qatar and the United Arab Emirates, universities are developing new programmes in the liberal arts, typically in association with American institutional partners, which prioritize active learning through discussion over rote-memorization (Al-Quds Bard College for Arts and Sciences n.d.; Berkowitz 2004; Bronner 2009; Fraenkel 2016; Jones 2015; NYU Abu Dhabi n.d.). In Morocco, male and female preachers are being trained at a new institute in Rabat that utilizes a broad-based curriculum and seeks to promote a tolerant and inclusive reading of Islam that directly challenges the claims of Salafi-jihadism. In numerous Arab states, a variety of government, civic and private actors are sponsoring art, music and book festivals; expanding cultural and historical programmes in cities designated as 'cultural capitals'; and participating in the formation of local environmental, women's rights and social science research and advocacy groups.

The involvement of religious actors and institutions in some of these initiatives raises an important question. Are the instances of humanist meaning-making underway in the Arab world necessarily secular in orientation? Let me make a brief detour to address this issue head-on.

\section{Religious trajectories of humanist culture change}

Whether or not humanism is compatible with faith in supernatural forces has long been a subject of heated debate, with many self-identified humanists contending that faith in any source of meaning beyond that originating in human endeavour is at odds with a humanist world-view, the idea being that all agency - and hence all ethical responsibility for the state of the world - lies with human beings alone. ${ }^{13}$ Yet historically, proponents of the values of human freedom and fellowship have drawn on religious as well as secular sources of inspiration. In America and Europe, the abolitionist movement and the women's rights movement drew on spiritual ideas associated with the Quaker, Unitarian and Congregationalist Christian faith traditions; in India, Mahatma Gandhi and Rabindrathe Tagore likewise drew on concepts of freedom and fellowship rooted in the philosophical and spiritual teachings of Hinduism. In much the same way, some Muslim scholars and activists in the Middle East and North Africa are seeking to revive the rich vein of humanistic Islamic thought and practice that coalesced at different junctures of place and time at both the elite and popular levels. In one clear example of this trend, in Morocco and Tunisia, some state-sponsored religious authorities, as 
well as independent imams and Islamist party activists, are working to increase public awareness of, and support for, a distinctive 'North African' version of Islam which, in their telling, is characterized by tolerance, compassion and respect for diversity, and bears the imprint of the region's long history as a geographic site of cross-cultural encounter and exchange. Such initiatives follow the successful recruitment of thousands of Moroccan and Tunisian youth into ISIS and other Salafi-jihadist groups, lending national debates about the meaning of Islam added urgency. The 'instrumentalization' of the humanist legacy of Islam to serve regime interests demands closer scrutiny, particularly when it is associated with the intensification of state intervention in and control of the religious sector. Yet even in cases where religious initiatives proceed from above and are driven in whole or in part by strategic considerations and designed to serve other ends, they can nevertheless work to augment the salience of humanist subcurrents in Arab-Islamic culture (see Berman 2016; Boum 2016; Feuer 2016; Malik 2014).

Among the cultural resources upon which Arab humanist initiatives can draw are Sufi beliefs and practices which have endured as a core element of popular culture in North Africa and elsewhere in the Muslim world. Sufism constitutes a complex symbolic field of thought and action that is nearly as difficult to define as Islam itself, yet at the discursive level, some common threads can be discerned. These include the concept of God's simultaneous transcendence and immanence, or presence within each human being, and the perfectibility of human nature through a rigorous process of spiritual training and discipline. Hence it represents an approach to Islam that prioritizes the inward quest of the seeker to achieve union with God; indeed, according to some Sufi teachers, it is this quest which constitutes the inner core of the faith, with the rulings of Shari'a, or Islamic law, functioning merely as its outer shell.

More broadly, Sufism includes registers of meaning which can be said to represent a distinctly Islamic form of humanism, one which views all human beings, and all Creation, as bearers of God's presence, and which asserts that the best way for believers to demonstrate their devotion to God is through acts of love and compassion. Indeed, it is through love that believers emulate God's qualities of mercy and compassion and fulfil their roles as God's awliyya - God's 'helpers' or 'friends. ${ }^{14}$ Such ideas are elaborated in the works of pre-modern Islamic philosophers such as al-Tawhidi (d. 1023), Miskawayh (d. 1030), Ibn al-'Arabi (d. 1240) and al-Jili (d. 1424). And traces of their imprint can be found in the 'popular' or 'folk' religious beliefs and practices of ordinary people in many parts of the Muslim world up to today. Though long denigrated by Salafi religious conservatives and secularists alike, the spiritual traditions of Sufism are starting to gain recognition as a vital component of the Arab-Islamic turath, or civilizational legacy, and as a rich source of humanist vision and insight for Muslims and non-Muslims alike. ${ }^{15}$

The origins, dynamics and effects of the humanist initiatives described above merit further research. Who are the architects of such initiatives, and what are their underlying motivations? What resources have they managed to mobilize, and what obstacles have they encountered, whether in the form of active resistance, social apathy or bureaucratic inertia? And most important of all, when, why and under what conditions have their efforts gained wider traction, whether at the micro level or as a catalyst of broader culture-shifts in society at large? 
Arriving at any definitive conclusion about the impact of such initiatives awaits the conduct of future research, and in the meantime we must be cautious not to overstate their effects. What can be said, however, is that such initiatives are directly affecting the rights, choices and experiences of the people whose lives they touch, and creating new templates of thinking and acting which, by their very existence, open up new possibilities for wider culture-shifts in the future. Whether or not and to what extent such broader change is realized will be shaped by broader features of the environment in which they are embedded. But much also depends on the will and capacity of those involved in such initiatives to navigate the obstacles strewn along their path. Whether they succeed or fail is impossible to predict. But the ability of human beings to marshal extraordinary levels of determination, tenacity and resolve to act in accord with their most deeply held values and commitments should not be underestimated. Moreover, in assessing the prospects for culture change, we must adopt a longer time horizon, as efforts to renegotiate meaning rarely produce instant results. The progression from micro-level initiatives to wider patterns of culture change in the Arab world is not inevitable, but nor is it definitively blocked. Rather, the future is open-ended and can be made better by those engaging in the art of the possible under existing institutional constraints.

\section{Conclusion}

The 'modest harvest' of the Arab Spring underscores the fact that the legacies of authoritarian rule can be fiercely resistant to reform. Yet to conclude that no change is possible in the region in the wake of recent setbacks goes too far. In this article, I have argued in favour of conceptualizing democratization as a multivalent process that encompasses changes occurring at different registers and unfolding through different causal sequences and according to different time lines, rather than as a fixed package of changes that proceed in unilinear fashion from different variants of authoritarianism towards a common democratic finish line. This rethinking of democratization entails a number of critical advantages. First, it enables us to move beyond the simplistic, all or nothing, characterization of a given society as democratic or not, allowing us to recognize that, whatever their current political arrangements, all societies entail a mix of disparate values, processes and relations of power which have conflicting implications for the bundle of public goods we normally associate with democratic governance. Second, it enables us to grasp democratization as a project that requires sustained human effort, takes generations to bear fruit and must be actively nurtured and refreshed in every society, including the consolidated democracies of the West. In so doing, it destabilizes characterizations of the Arab world as implacably 'Other' and highlights the challenges that all complex modern societies share in common.

Third, it offers fresh perspective on the obstacles to - and possibilities for democratic change in the Arab world today. On the one hand, it reveals that expectations that the Arab Spring protests would yield 'instant democracy' were tragically naive. On the other, it highlights the possibilities for creative social experimentation within a wide variety of institutional settings. As noted above, humanist initiatives in the fields of education, religion and culture can generate new habits of mind and behaviour with or without the concurrence of democratic regime change or 
dramatic increases in economic growth. Ignoring or dismissing such initiatives, however fragile, tenuous and open-ended they may be, leads us to exaggerate the degree of stasis in the Arab world in the post-Spring era. Just as importantly, it falsely denies the region's citizens any locus of meaningful agency unless and until the macro political and economic structures in which they are embedded undergo a wholesale transformation. In so doing, it reinforces learned helplessness rather than resilience. ${ }^{16}$

In closing, let me stress that none of the foregoing analysis should be seen as denying the existence of many structural obstacles to democratization in the Arab world or ignoring the pernicious effects of the region's recent authoritarian turn. The purpose of this article is not to give current authoritarian rulers a pass or attempt to prettify systems in which asymmetrical power relations are maintained through coercion and intimidation. Nor is it to deny that current restrictions on freedom of expression and assembly make it difficult for citizens to mobilize against incumbent regimes without incurring tremendous costs.

Rather, I have sought to make the case for maintaining two seemingly contradictory images of the Arab world in our minds simultaneously. The first image forefronts the persistence of macro political and economic structures which, with the lone exception of Tunisia, are headed by unelected rulers, sustained through coercion and resistant to democratic reform. This image underscores the importance of continued efforts by individuals, groups, movements and organizations to challenge such arrangements head-on. The second image depicts these same systems at a more granular level, with an eye for the institutional openings, tensions and discontinuities which create spaces for creative social experimentation. In so doing, it alerts us to the presence of counter-currents and trends that get obscured when we focus solely on macro power dynamics and/or aggregate trends in public opinion.

These two images do not contradict each other, but rather focus on different phenomena. The first highlights the persistence of authoritarian systems of power, while the latter highlights the possibilities for social innovation within them. Both of these images are valid, yet both are incomplete without the other. Holding these two images of the Arab world in mind simultaneously enables us to acknowledge existing obstacles to change while avoiding the distortions that result from making them our only focus. In the wake of the Arab Spring, the arc of the region curves towards constraint, but the circle isn't closed. To suggest otherwise is to impose a veneer of absolute stasis on a more variegated and complex reality.

Acknowledgements. This article builds on the 2018 Government and Opposition/Leonard Schapiro Lecture, given at the Political Studies Association's annual conference in Cardiff, 27 March 2018.

\section{Notes}

1 Some of the best comparative scholarly treatments of this question include: Bellin (2018); Chalcraft (2016); Grand (2014); Hinnebusch (2015); Lynch (2016); Nepstad (2011); Reynolds et al. (2015). See also my explanation for the collapse of Egypt's brief democratic transition in the Afterword to Wickham (2015).

2 Much of this literature focuses on what is known as the 'third wave' of democratization, a global cascade of democratic transitions which began in Southern Europe in the 1970s and, over the next few decades, extended to countries in Latin America, Eastern Europe, East Asia and Sub-Saharan Africa as well. 
Some of the most influential works include: Haggard and Kaufman (2016); Huntington (1993); Linz and Stepan (1996); Schmitter et al. (1986).

3 There is no scholarly consensus on how to define 'humanism'. The term has been used to describe a comprehensive world-view, a system of ethics, a type of literature and an educational curriculum; in addition, the core ideas associated with it lend themselves to multiple and conflicting interpretations. One key point open to debate is whether humanism is by definition secular, i.e. rejects any supernatural or transcendent dimension to human existence. Another is whether it is uniquely a product of Western civilization - beginning with the philosophers of classical Greece and Rome and flowering during the European Renaissance and the Enlightenment - or can be found in the beliefs and practices of other world civilizations as well.

4 Verba and Almond's seminal work continues to serve as a launching point for political science research. See Dalton and Welzel (2014); Muller and Seligson (1994). See also Campbell and Conradt (2015).

5 For a more expansive approach to politics which extends to all areas of society in which power is generated and deployed, see Leftwich (2004: 1-22).

6 For more on the Sufi practice of tazkiyat an-nafs, see Chittick (2000: 40-45); for an excellent analysis of the same practice, described here as jihad al-nafs, see Shaikh (2009).

7 The literature on the communitarian critique of liberalism is vast. For a good overview of communitarian thought, see Etzioni (2011). Other helpful references include Avineri (1992); Griffin (1988); Thigben and Downing (1987).

8 For an application of Rustow's theory to the Middle East, see Waterbury (2001). For Mehran Kamrava (2007: 212), democratic transitions hinge not on inter-elite bargains but on the empowerment of societal actors in relation to the state. Yet here too, cultural values matter little for the outcome. As he argues: 'By itself ... culture is not a maker or breaker of democratization. It is, in fact, far less significant of a force than the institutional, political, and financial resources at the disposal of the state elites on one side and social actors on another.

9 See Schmitter and Karl (1991: 11): 'Our assertion is that contingent consent and bounded uncertainty can emerge from the interaction between antagonistic and mutually suspicious actors and that the far more benevolent and ingrained norms of a civic culture are better thought of as a product and not a producer of democracy' [Italics in the original].

10 The idea that, in its later stages, economic development becomes a process of human emancipation, is reiterated numerous times in the text. As they note, 'Rising self-expression values transform modernization into a process of human development, generating a society that is increasingly people-centered. This reflects a humanistic transformation of modernity' (Inglehart and Welzel 2005: 3). It is reiterated later: 'Most important, emerging self-expression values transform modernization into a process of human development, giving rise to a new type of humanistic society that promotes human emancipation on many fronts ... This process reflects a humanistic transformation of modernization' (Inglehart and Welzel 2005: 47). The same argument is emphasized in the book's concluding chapters (see especially Inglehart and Welzel 2005: 295297, 299-300).

11 As Inglehart and Welzel note, the distinction between 'institutionalists' and 'culturalists' derives from the difference in how they see the causal relationship between mass values and democratic institutions. For more on this distinction, see Inglehart and Welzel (2005: 173).

12 For further discussion of the concept of 'prefigurative politics', see Yates (2015).

13 See the definition of humanism on the website of the American Humanist Association (https://americanhumanist.org/what-is-humanism/definition-of-humanism), which defines humanism as a progressive life stance without theism or other supernatural beliefs. A similar definition is offered on the website of the British organization, HumanistsUK (https://humanism.org.uk/humanism). See also Jacoby (2004).

14 The concept of the believer as 'friend' or 'helper' of God can be found in Christian and Jewish mystical traditions as well. In the Christian mystical tradition, one finds the 'Celi Dei' and 'Gottesfreunde'; in Jewish Kabbalah, there is the idea of human beings participating with God in 'tikkun olam', the repair of the world. 15 For more on Sufism and its relationship to other forms of Islamic thought and practice, see Ahmed (2016). See also Chittick (2000); Knysh (2017); Reichmuth et al. (2012); Schimmel (2011); Shaikh (2012). 16 For more on the social modalities of resilience under conditions of extreme adversity, see two pathbreaking works on the Native American experience: Lear (2008) and Treuer (2019). See also Blackhawk (2019). 


\section{References}

Ahmed S (2016) What is Islam? The Importance of Being Islamic. Princeton: Princeton University Press. Almond G and Verba S (eds) (1980) Civic Culture Revisited. Boston, MA: Little, Brown.

Al-Quds Bard College for Arts and Sciences (n.d.) About Us: Partnership. https://bard.alquds.edu/about$\mathrm{aqb} /$ partnership.html.

Avineri S (ed.) (1992) Communitarianism and Individualism. Oxford: Oxford University Press.

Badran M (1998) Gender, Islam and the State: Kuwaiti Women in Struggle, Pre-Invasion to Post-Liberation. In Haddad Y and Esposito J (eds) Islam, Gender and Social Change. Oxford: Oxford University Press, pp. 190-208.

Bayat A (2015) Revolution and Despair. Mada Masr, 25 January, https://madamasr.com/en/2015/01/25/ opinion/u/revolution-and-despair.

Bellin E (2004) The Robustness of Authoritarianism in the Middle East: Exceptionalism in Comparative Perspective. Comparative Politics 36(2), 139-157.

Bellin E (2018) Explaining the Puzzle of Democratic Divergence: Theory Confronts Experience in Egypt and Tunisia. Political Science Quarterly 133(3), 435-474.

Berkowitz P (2004) The Liberal Arts in Kuwait. 28 January, https://peterberkowitz.wordpress.com/2004/01/28.

Berman I (2016) Morocco's Islamic Exports: The Counter-Terrorism Strategy Behind the Mohammed VI Institute for the Training of Imams, Snapshot. Foreign Affairs, 12 May.

Berman S (1997) Civil Society and the Collapse of the Weimar Republic. World Politics 49(3), 401-429.

Blackhawk N (2019) The Heartbreak of Wounded Knee. Book review, New York Times, 20 January.

Boum A (2016) Morocco's Program for Securing Religious Toleration: A Model for the Region? Sightings, Martin Marty Center for the Advanced Study of Religion, University of Chicago Divinity School, 18 March, https://divinity.uchicago.edu/sightings/moroccos-program-securing-religious-toleration-modelregion.

Bronner E (2009) Palestinian Campus Looks to East Bank (of Hudson). New York Times, 14 February.

Campbell R and Conradt DP (2015) The Civic Culture at 50: Change, Continuity and Challenges in the Federal Republic of Germany. German Politics 24(3), 249-270.

Cavatorta F (2015) The Rise and Fall of Uncivil Society? Salafism in Tunisia after the Fall of Ben Ali. Essay, Middle East Institute website, 6 October, www.mei.edu/publications/rise-and-fall-uncivil-society-salafism-tunisia-after-fall-ben-ali.

Chalcraft J (2016) The Arab Uprisings of 2011 in Historical Perspective. In Ghazal A and Hanssen J (eds), The Oxford Handbook of Contemporary Middle Eastern and North African History. Published online January, https://doi.org/10.1093/oxfordhb/9780199672530.013.13.

Chittick WC (2000) Sufism: A Short Introduction. Oxford: Oneworld.

Dalton R and Welzel C (eds) (2014) The Civic Culture Transformed: From Allegiant to Assertive Citizens. Cambridge: Cambridge University Press.

Deeb L (2006) An Enchanted Modern: Gender and Public Piety in Shi'i Lebanon. Princeton: Princeton University Press.

Deutsch K (1961) Social Mobilization and Political Development. American Political Science Review 55(3), 678-679.

El Feki S, Heilman B and Barker G (eds) (2017) Understanding Masculinities: Results from the International Men and Gender Equality Survey (IMAGES) - Middle East and North Africa. Cairo and Washington, DC: UN Women and Promundo-US. https://promundoglobal.org/resources/understanding-masculinities-results-international-men-gender-equality-survey-images-middle-east-north-africa.

Elshinnawi M (2016) Arab Spring Became Brutal Winter, Analysts Say. Voice of America, 19 January, www. voanews.com/a/arab-spring-brutal-winter-analysts-say/3153382.html.

Etzioni A (2011) Communitarianism. Encyclopaedia Britannica, www.britannica.com/topic/communitarianism.

Feuer S (2016) State Islam in the Battle Against Extremism: Emerging Trends in Morocco and Tunisia. Policy Focus 145. Washington Institute for Near East Policy, June.

Fraenkel C (2016) Teaching Plato in Palestine. Princeton: Princeton University Press.

Grand SR (2014) Understanding Tahrir Square: What Transitions Elsewhere Can Teach Us About the Prospects for Arab Democracy. Washington, DC: Brookings Institution Press.

Griffin DR (ed.) (1988) Spirituality and Society. Albany: State University of New York Press. 
Gunning J and Baron IZ (2014) Why Occupy a Square? People, Protests and Movements in the Egyptian Revolution. Oxford: Oxford University Press.

Haggard S and Kaufman RR (2016) Dictators and Democrats: Masses, Elites and Regime Change. Princeton: Princeton University Press.

Hinnebusch R (ed.) (2015) From Arab Spring to Arab Winter: Explaining the Limits of Post-Uprising Democratisation. Democratization Special Issue, 22(2).

Huntington S (1993) The Third Wave: Democratization in the Late Twentieth Century. Norman: Oklahoma University Press.

Inglehart R and Welzel C (2005) Modernization, Cultural Change, and Democracy: The Human Development Sequence. Cambridge: Cambridge University Press.

Jacoby S (2004) Freethinkers: A History of American Secularism. New York: Metropolitan Books, Henry Holt and Company.

Jones CW (2015) Seeing Like an Autocrat: Liberal Social Engineering in an Illiberal State. Perspectives on Politics 13(1), 24-41.

Kamrava M (2007) The Middle East's Democracy Deficit in Comparative Perspective. Perspectives on Global Development and Technology 6(1), 189-213.

Knysh A (2017) Sufism: A New History of Islamic Mysticism. Princeton: Princeton University Press.

Laitin D (1995) The Civic Culture at 30. American Political Science Review 89(1), 168-173.

Lear J (2008) Radical Hope: Ethics in the Face of Cultural Devastation. Cambridge, MA: Harvard University Press.

Leftwich A (ed.) (2004) What is Politics? The Activity and its Study. Cambridge: Polity Press.

Lerner D (1958) The Passing of Traditional Society: Modernizing the Middle East. New York: Free Press.

Lichterman P (2012) Reinventing the Concept of Civic Culture. In Alexander JC, Jacobs RN and Smith P (eds), The Oxford Handbook of Cultural Sociology. Oxford: Oxford University Press, pp. 207-231.

Linz J and Stepan A (1996) Problems of Democratic Transition and Consolidation: Southern Europe, South America and Post-Communist Europe. Baltimore: Johns Hopkins University Press.

Lipset SM (1959) Some Social Requisites of Democracy: Economic Development and Political Legitimacy. American Political Science Review 53(1), 69-105.

Lynch M (2016) The New Arab Wars: Uprising and Anarchy in the Middle East. New York: Public Affairs/ Perseus Books.

Malik H (2014) The Struggle for Religious Identity in Tunisia and the Maghreb. Center for Strategic and International Studies Analysis Paper, 2 May.

Moghadam VM (ed.) (1994) Gender and National Identity: Women and Politics in Muslim Societies. Houndmills: Palgrave Macmillan.

Muller EN and Seligson MA (1994) Civic Culture and Democracy: The Question of Causal Relationships. American Political Science Review 88(3), 635-652.

Nepstad SE (2011) Nonviolent Resistance in the Arab Spring: The Critical Role of Military-Opposition Alliances. Swiss Political Science Review 17(4), 485-491.

NYU Abu Dhabi (n.d.) History. https:/nyuad.nyu.edu/en/about/nyuad-at-a-glance/history.html.

Pavone T (2014) Political Culture and Democratic Homeostasis: A Critical Review of Gabriel Almond and Sidney Verba's The Civic Culture. Princeton University, 7 April, https://scholar.princeton.edu/sites/ default/files/tpavone/files/almond_verba-_the_civic_culture_critical_review_0.pdf.

Raekstad P (2018) Revolutionary Practice and Prefigurative Politics: A Clarification and Defense. Constellations 25(3), 359-372.

Reichmuth S, Rusen J and Sarhan A (eds) (2012) Humanism and Muslim Culture: Historical Heritage and Contemporary Challenges. Taipei: National Taiwan University Press.

Reynolds A, Brownlee J and Masoud TE (2015) The Arab Spring: Pathways of Repression and Reform. New York: Oxford University Press.

Rustow D (1970) Transitions to Democracy: Toward a Dynamic Model. Comparative Politics 2(3), 337363.

Schimmel AM (2011) The Mystical Dimensions of Islam, 2nd edn. Durham: University of North Carolina Press.

Schmitter PC and Karl TL (1991) What Democracy Is ... and Is Not. Journal of Democracy 2(3), 75-88.

Schmitter PC, O'Donnell G and Whitehead L (1986) Transitions from Authoritarian Rule: Tentative Conclusions about Uncertain Democracies. Baltimore: Johns Hopkins University Press. 
Sen A (1999) Development as Freedom. New York: Alfred A. Knopf.

Shaikh S (2009) In Search of al-Insan: Sufism, Islamic Law and Gender. Journal of the American Academy of Religion 77(4), 790-792.

Shaikh S (2012) Sufi Narratives of Intimacy: Ibn 'Arabi, Gender, and Sexuality. Durham: University of North Carolina Press.

Thigben RB and Downing LA (1987) Liberalism and the Communitarian Critique. American Journal of Political Science 31(3), 637-655.

Treuer D (2019) The Heartbreak of Wounded Knee: Native America from 1890 to the Present. New York: Riverhead Books.

UNDP (2005) Arab Human Development Report 2004: Towards Freedom in the Arab World. New York: United Nations Development Program.

Verba S (2015) The 50th Anniversary of The Civic Culture. German Politics 24(3), 234-248.

Verba S and Almond GA (1963) Civic Culture: Political Attitudes and Democracy in Five Nations. Princeton: Princeton University Press.

Washington Post (2011) Remarks of President Obama: 'A Moment of Opportunity', 19 May, www. washingtonpost.com/world/remarks-of-president-barack-obama-a-moment-of-opportunity/2011/05/19/ AFMP0F7G_story.html?noredirect=on\&utm_term $=.720$ c08346923.

Waterbury J (2001) Democracy Without Democrats? Potential for Political Liberalization in the Middle East. In Salame G (ed.), Democracy Without Democrats: The Renewal of Politics in the Muslim World. London: I.B.Tauris, pp. 23-47.

Wickham CR (2002) Mobilizing Islam: Religion, Activism and Political Change in Egypt. New York: Columbia University Press.

Wickham C (2015) The Muslim Brotherhood: Evolution of an Islamist Movement. Princeton: Princeton University Press.

Yates L (2015) Rethinking Prefiguration: Alternatives, Micropolitics and Goals in Social Movements. Social Movement Studies 14(1), 1-21.

Cite this article: Wickham CR (2020). Rethinking the Origins of Civic Culture and Why it Matters for the Study of the Arab World (The Government and Opposition/Leonard Schapiro Lecture 2018). Government and Opposition: An International Journal of Comparative Politics 55, 1-20. https://doi.org/10.1017/ gov.2019.12 